\title{
Vulnerable GMOs and U.S. Agriculture
}

\author{
Sam Delphin \\ Agricultural Biochemistry, University of Missouri, Columbia, U.S.A. \\ *Corresponding author: delphins@missouri.edu
}

\begin{abstract}
Human genetically-modified organism(s)," abbreviated as, "GMOs," or, as labeled in this article, "transgenic agricultural crops," first became technologically and commercially available some twenty years ago and have become the dominant varieties of many staple crops in the U.S., especially, corn, soybeans, and cotton. In 2014 the United States Department of Agriculture (USDA) published a thorough consideration of transgenic crops including detailed surveys and summarized field research. The experiences from the last twenty years are more ambivalent about the value of transgenic crops than when the transgenic concept was originally devised. Within the present context of cloned, transgenic crops, disestablished federal crop reserves, cursory inspections of imported foreign crops, and the reality of past U.S. homogenous-crop devastations from unanticipated vectors, U.S. agriculture appears highly vulnerable.
\end{abstract}

Keywords: GMOs, transgenic, agricultural crops, crop reserves, 'just in time' crop imports, homogenous-crop devastations

Cite This Article: Sam Delphin, "Vulnerable GMOs and U.S. Agriculture." World Journal of Agricultural Research, vol. 5, no. 4 (2017): 240-243. doi: 10.12691/wjar-5-4-6.

\section{Introduction}

In the late summer of 1969 a fungus named 'southern corn leaf blight' was identified but was estimated a minor threat. With supportive, humid spring and summer weather conditions, seasonally predominant south to north winds, and a widely planted, single variety of a particularly susceptible hybrid corn, southern corn leaf blight went epidemic in 1970. First appearing in southern Florida the blight spread through corn crops in Alabama and Mississippi and week by week spread up through the U.S. 'corn belt' extending from Texas to the East Coast and up through the U.S. to southern Ontario. Fortunately, sufficient federal surplus stores of corn and grains maintained acceptable consumer prices in 1970. Having widely planted federal surpluses of diverse, non-susceptible, hybrid corn varieties' seeds and unusual, drier, very cool summer evening temperatures covering much of the Midwest, the blight all but disappeared in 1971. Crop scientists at that time observed, "The experience with southern corn leaf blight emphasizes that the hazards of growing the same genotype of a crop on extensive acreage applies to characters inherited through the cytoplasm [the constituents of the cell surrounding the nucleus] as well as those inherited through the nucleus [the genetic material]" [1]. And, in the original, all in italics for emphasis, "Diversity must be maintained in both genetic and cytoplasmic constitution of all important crop species" [2].

\section{Discussion}

In 2014 the United States Department of Agriculture (USDA) published a thorough consideration of transgenic
U.S. crops including detailed surveys and summarized field research which indicates several critical issues facing transgenic agriculture [3].

\subsection{Transgenic Crops' Overview}

In current years, transgenic crops have been widely adopted by U.S. farmers. Dating from the transgenic crop seeds' commercial introduction in 1996, transgenic varieties now dominate corn (90 percent in 2013), cotton (90 percent), and soybean plantings (93 percent) [[3], p. 9]. This dominance of transgenic crops in the U.S. also applies to Brazil and Argentina [[3], p. 9]. European countries are much more cautious and other countries slower adopting or developing their own varieties of transgenic crop seeds [4], [[3], p. 9].

Over almost two decades there have been overwhelming transgenic varieties of corn (7,778 varieties), soybeans $(2,225)$, cotton $(1,104)$, and other crops such as potatoes (904) and tomatoes (688) introduced after field testingeach transgenic crop variety is required to be field tested and its attributes investigated by the USDA Animal and Plant Health Inspection Service (APHIS) and, if toxicologically pertinent, by the Food and Drug Administration (FDA) and Environmental Protection Agency (EPA). Usually, only the most recent varieties of transgenic crop plants are widely marketed for agriculture in the U.S. and these increasingly involve "stacked" traits such as a transgenic crop plants' resistance to a herbicide directed against weeds plus a transgenic crop plants' selfcontained insecticide production, these along with finaluser nutrient enhancements. Such "stacked" transgenic corn has grown from 9 percent of the U.S. corn acreage in 2005 to 71 percent in 2013 [[3], p. 17]. The herbicide resistant varieties allow farmers' use of the weed herbicide, 
glyphosate, while the insecticidal transgenic varieties incorporate genes from a soil bacterium, Bacillus thuringiensis $(\mathrm{Bt})$, which genes produce a protein which is toxic to certain insects. The Bt transgenic crop plants carry the insecticidal trait through the plant's lifetime [[3], p. 1].

\subsection{Transgenic Crops in the Field}

However, some studies indicate the use of the weed herbicide, glyphosate, while not attacking the transgenic crop, glyphosate sprays may leave residue on the transgenic plants which may be directly or indirectly (i.e., in conjunction with other toxins) harmful to mammals [[3], p. 25]. There is also evidence that weeds can evolve over years to resist glyphosate as demonstrated in studies indicating that 14 major weed varieties are now less affected [[3], p. 32]. With no new commercial herbicides developed over the past two decades, slowing the rate of weed resistance to glyphosate is one of the most important issues facing U.S. agriculture in the opinions of many plant scientists [[3], p. 32]. Proposals include developing another long-lasting herbicide to be used with glyphosate, and falling back on past practices, including rotating crops - changing crops may potentially limit or reduce particular weeds adapting to a transgenic crop's herbicide protocol-and increasing cultivation operations, such as harrowing between and around rows on transgenic crop fields to reduce herbicide-surviving weeds' reproduction. Also suggested for slowing weed resistance to glyphosate is cleaning equipment thoroughly and frequently between fields to avoid re-introduction of weeds which would possibly facilitate their evolving herbicide resistance and more care in applying glyphosate at the prescribed solution strength and using its spraying techniques exactly as specified [[3], p. 32].

Against insect damage, the Bt soil bacterium has genes producing an insecticidal protein, identified as deltaendotoxin, ' $\delta$-endotoxin', which forms a specific crystal in the vulnerable insect species' gut, subsequently penetrating the lining, and that puncture leads to septicemia. With mammalian stomach acids and more developed stomach linings this specific delta-endotoxin has shown no mammalian toxicity [[5], p. 31]. The Bt insecticide is only effective when some of the plant is actually eaten by the insect, but the insect is assumed to quickly succumb to the Bt transgenic protein's toxicity so that anticipated plant damage is projected to be less than without. Regarding transgenic Bt maintaining insect toxicity, in 77 studies on 5 continents, 1996-2012, researchers noted 5 out of 13 major pest species were evolving resistance to the $\mathrm{Bt}$ transgenic-protein [[3], p. 29].

Where transgenic $\mathrm{Bt}$ is planted, the EPA now requires the planting of close-by 'refuge' acreage of non-transgenic crop plants, using the same non-transgenic source-species and variety as initiated the transgenic crop, to allow some pests to develop in proximity to the transgenic crop and relying on general interbreeding of the Bt exposed insect pests - some of which may become resistant to Bt's transgenic-protein - with non-transgenic exposed cohorts. Facilitating inter-breeding, researchers hope, will be more likely to maintain the pest species' general lack of resistance to the Bt transgenic-protein [[3], p. 29]. However, too, unless the transgenic crop plants are sterile, the refuge's proximity of non-transgenic crop plants to transgenic crop plants of the same species and variety can allow cross-pollination of the two crops and any resulting seeds of the transgenic plant's and crop plant's hybrid will have unknown characteristics.

Apart from increasing weed tolerance of the herbicide, glyphosate, and insects acquiring tolerance of the insecticidal protein from $\mathrm{Bt}$, the identical homogeneity and widespread cropping of transgenic-cloned seeds and plants may leave the transgenic crops particularly vulnerable to scientifically unanticipated insect, disease, and fungal attacks. The countrywide planted crops' identical, engineered, cloned sameness seems too similar to the past U.S. grains and hybrid grains which suffered crop-wide disease and fungal attacks.

\subsection{Risks of Transgenic Homogeneity}

In fairly recent times the U.S. has experienced northern corn blight 1939-1943 with substantial but not estimated dollar losses, then 65 percent destruction of the durum wheat crop with 25 percent of the bread wheat crop in 1953 followed by 75 percent of durum and 25 percent of bread wheat crops loss in 1954. The Barley Yellow Dwarf virus attacked barley and oats most significantly between 1951-1959. Spread by plant lice the virus in 1959 caused up to an estimated 50 percent loss of oats, 30 percent of wheat, and 20 percent of barley in one record keeping state. The virus and carrier lice were identified as endemic to U.S. wild grasses, spread to Europe and Australia, and only development of resistant crop hybrids offered significant hope for future crops [6, pp. 178-179]. Maize dwarf-mosaic virus significantly reduced the corn crop in 1962. This is another virus endemic to native vegetation and introduced by aphids into such crops as corn, mottling the corn leaves with tiny patterns, and can halt corn ear formation. Researchers have developed hybrids better able to resist the virus. More recently, the southern corn leaf blight in 1970 rotted the kernels on the ears of corn and left overall losses estimated at 20-30 percent of the U.S. crop while some areas in the major corn growing states suffered losses of 50-100 percent and the cost of such losses was estimated at nearly a billion dollars $[1,2]$.

\section{Federal Crop Reserves Sold-off}

Now the Commodity Credit Corporation of the USDA Farm Service Agency shows in its 2013 Annual Management Report no reserves whatsoever during the last three years, no reserves for corn, wheat, rice, nor soybeans and this lack of reserves to the present is confirmed by staff in Commodity Operations at USDA's Farm Service Agency and continuing Commodity Credit Corporation reports [7]. Since the 1996 Farm Bill repealed federal crop reserves there are no longer federal grain reserves [8]. Any major U.S. crop losses to pests, fungi, or diseases would become economically disastrous for the country. 


\section{4. "Just in Time" Importing}

U.S. agribusinesses are now allowed to import, 'just in time', cheaper harvests from other countries, avoiding U.S. quarantine planting or quarantine holding for careful observation, and, therefore, imported regardless of any insect, fungal, bacterial, or viral infections as long as an infection is not widely publicized or known or spotted in a USDA import inspection.

In Hawaii papaya ring-spot virus (PRSV), began making papaya skin undesirable with virus-rotted, expanding circles, 'ring-spots'. The virus, evidently spread mainly by aphids, cut production of Hawaiian papaya in half between 1992 to 1998 in spite of grower attempts to isolate the papaya crops in former sugar cane fields and researchers' trials to find a PSRV-resistant papaya variety. Transgenic engineering uses amino acid sequences of the PSRV's coat, the virus's own coat, inserted into the skin genes of a hybrid papaya with the common name, 'Rainbow'. The transgenic PRSV-papaya skin achieves a strategy of PRSV self-avoiding, 'pathogen-derived resistance' $[9,10]$. The, now, hybrid-transgenic papaya variety 'Rainbow' became available for commercial planting in 1998, and since then no breakdown in resistance to the PRSV has been detected for Hawaiian hybrid-transgenic 'Rainbow' papaya [10]. Ongoing, since 'Rainbow' is a hybrid of the 'SunUp' and 'Kapoho' varieties of papaya, this PRSV resistance trait as well as other desirable traits are doubtfully inheritable in 'Rainbow' seeds so must always be technically introduced during 'SunUp' and 'Kapoho' hybridization.

In 1990 Florida orange trees exhibited damage from citrus 'tristeza' virus apparently spread by brown aphids. The virus is thought to have originated from Spain, Portugal, or South America. In 2000 Florida oranges began showing symptoms of 'citrus cankers' from an unknown source country. Currently Florida oranges are majorly threatened by Asian 'citrus greening'.

The Asian citrus psylla (a lice-like insect), thought to originate from China, first appeared in Florida in 2005. The citrus psylla carry an alpha-proteobacterium which causes the disease 'citrus greening' or in the Chinese name's phonics, huáng-lóng-bing, 'yellow dragon disease', (abbreviated by English speakers as 'HLB'). The proteobacterium, injected by the psylla bite into stems and leaves of citrus trees, parasitize and multiply exponentially in the sap, weakening the tree, increasing the tree's susceptibility to other afflictions or stresses, reducing acceptable fruit production to some $60 \%$ compared with healthy trees, and for severely affected trees retarding oranges to green, bitter tasting, non-developing drupes. By one estimate 80 percent of Florida's orange trees are currently infected and orange crop growing in general may be threatened. The HLB disease is now thought to be in every citrus growing region of the U.S. also affecting lemons, grapefruit, and mandarin citrus fruits such as tangerines. Insecticidal spraying against the psylla has not completely controlled the spread of HLB. Scientists hope to develop for orange trees and other citrus species some transgenic resistance to HLB $[11,12]$. However, experience, as mentioned above with transgenic corn, soybeans, and cotton, indicates that any defensive transgenic measure may be overcome in time through resistance adaptation of baneful weeds and devastating pests.

\section{Conclusions}

No longer the panacea they had seemed to be, transgenic-cloned crops have equal and greater vulnerabilities from widespread, suppression-resistanceevolving, predator insects, diseases, and fungi and, likewise, herbicide-resistance-evolving, yield-suppressing weeds, or, further, potential epidemics of unanticipated predator insects, diseases, or fungi on countrywide fields of transgenic-cloned plants.

Too, the naïve optimism allowing 'just in time' global sourcing for plants and crops without requiring careful quarantine planting or quarantine holding along with the U.S. government abandonment of strategic grain and seed reserves now leaves the U.S. food supply especially vulnerable.

Reconsidering the short-term, patent-monopoly revenues of transgenic crops and overwhelming favoritism towards transgenic crop research, how might U.S. crops be ecologically planned towards longer-term, sustainable prosperity? How might 'just in time' imported crops, in addition to prior U.S.D.A. prohibitions and arrival safety inspections, be financially bonded or insured or held accountable against causations introducing major crop damage? And, how might U.S. essential-crop reserves be re-established and cycled to serve as sufficient, viable, emergency-replacements, sufficient for consumption and planting, yet maintain viable on-going, current markets for U.S. produced commodities?

\section{References}

[1] L. A. Tatum, "The Southern Corn Leaf Blight epidemic," Science, 171. 1113-1116. 1971.

[2] A. J. Ullstrup, "The impacts of the Southern Corn Leaf Blight epidemics of 1970-1971," Annual Review Phytopathology, 10. 3750. 1972.

[3] J. Fernandez-Cornejo, S. Wechsler, M. Livingston, L. Mitchell, "Genetically Engineered Crops in the United States," ERR-162, United States Department of Agriculture, Economic Research Service, 2014. Available:

https://www.ers.usda.gov/publications/pubdetails/?pubid=45182. [Accessed July 2, 2017].

[4] J. Davison, "GM Plants: Science, politics, and EC regulations," Plant Science, 178 (2). 94-98. 2010.

[5] "Consensus Document on Safety Information on Transgenic Plants://www.oecd.science/biotrack/46815888.pdf. [Accessed July 2, 2017].

[6] G. L. Carefoot, E. R. Sprott. Famine on the Wind: Man's Battle Against Plant Disease, Rand McNally, N.A., 1967.

[7] “2013 Annual Management Report,” USDA Farm Service Agency, Commodity Credit Corporation, Available: https://www.fsa.usda. gov/Internet/FSA_File/ccc_annual_report_2013.pdf. [2013 commodity inventories: computer pp. $91-92$; paper pp. 85-86, 2014].[ Accessed July 2, 2017]. Updates, including January, 2016, Also available:

https://www.fsa.usda.gov/programs-and-services/commodityoperations/commodity-operations-reports/index.[Accessed July 2, 2017].

[8] 2015 e-mail from a National Agricultural Library Reference Librarian and the librarian's contact at USDA, Farm Service Agency, Commodity Operations. "The 1996 Farm Bill repealed 
the grain reserve programs and USDA currently has no grain reserve programs."

[9] S. Tripathi, J. Y. Suzuki, S. A. Ferreira, D. Gonsalves, "Papaya ringspot virus- $P$ : characteristics, pathogenicity, sequence variability, and control." Molecular Plant Pathology, 9 (3). 269-280. 2008.

[10] 2016 PRSV e-mail information from a senior researcher at USDA's Agricultural Research Service in Hawaii who has requested no public listing.
[11] P. Voosen, "Can Genetic Engineering Save the Florida Orange?" National Gegraphic,. Sept. 14, 2014. Available:

http://news.nationalgeographic.com/news/2014/09/140914

florida-orange-citrus-greening-gmo-environmentscience/.[Accessed July 2, 2017].

[12] 2016 HLB e-mail information from a senior researcher at USDA's Agricultural Research Service in Florida who has requested no public listing. 